\title{
Public Health in Europe during the Covid-19 Emergency
}

\author{
Ubaldo Comite \\ Associate Professor of Business Administration \\ Faculty of Law, Online University \\ "Giustino Fortunato", Benevento \\ Italy
}

\begin{abstract}
In line with what has happened in other sectors of the Public Administration, where the change process has, as an objective, the search for efficiency and efficacy, in Italy, the awareness that an efficient, effective and equal healthcare service is a major success factor for the socio-economic development of each is growing. The healthcare system is at the centre of great attention, having to demonstrate the adequate use of constantly decreasing available resources against a growing healthcare demand. This entails an incentive oriented toward the ability to improve services. Such need has been consolidating in the overall corporatization process, leading to a growing orientation toward performance and to the use of programming tools. In this context must be considered the diseases characterized by the length of the healthcare assistance plan and high complexities in terms of treatments and complications. Such diseases are relevant in epidemiological terms and also in terms of resources employed and improvement potential from the point of view of intervention policies, of public healthcare offer and of efficiency. The above may refer to the healthcare emergency still in place following the spread of the COVID-19 virus, employing an enormous amount of resources from both a human and a financial point of view. SARS-CoV-2, a serious threat to sustainable development prospects, is spreading within countries at varying speeds, among other things depending on their population density, behavioural responses, cultural factors, personal hygiene practices and habits. This has led to significant variation in countries' policy responses aimed at stemming the proliferation of the virus. Using crisp-set qualitative comparative analysis, we conducted a comparative study at the European level to study the performance of different combinations of COVID-19 containment measures along with the response speeds. A set of configurations for two different scenarios (above-and below-median death rates) helps to illustrate how specific containment measures in each examined European country are related to the number of deaths. The main observation arising from the analysis is that the speed of response along with the decision to suspend international flights might determine the epidemic outbreak's impact on fatality. The results also imply that several different combinations of containment measures are associated with death rates across Europe. The outcome of this analysis can assist in identifying which set of containment measures in the event of an epidemic outbreak is beneficial/detrimental.This work considers combining theoretical considerations and empirical evidence related to the treatment of COVID-19, within what it is the success of public health measures in Europe during the COVID-19 emergency.
\end{abstract}

Keywords:Healthcare, COVID-19, Pandemic, service, efficiency, management, assistance, emergency, containment measures

JEL classification: M1, M10, M14, I 1, I 10

Paper Type: Research study.

\section{Introduction}

The higher purpose of any Government is to promote the dignity of its citizens, avoiding the identification of people like mere tools to reach political and financial objectives. If any Government considers people as an absolute value and wants to grant their dignity, it must ask itself what are their ambitions and their qualities. Only by trying to answer to these questions it will allow them, available resources permitting, to satisfy their ambitions: in other words, to promote the dignity of a nation means to guarantee its citizens the capability and freedom to make and implement their own choices. Obviously, such capability depends from individual abilities (influenced by genetics and by environmental factors), from the political, social and financial context and, indeed, from the general health conditions. It is the indicators related to our state of health that allow the Country to enhance us: the life expectancy at birth, the quality of life free from diseases and disabilities, the ability to keep a good state of health, the psychological well-being, the possibility to express feelings and emotions, the attitude toward environmental preservation. 
Governments, therefore, need to invest in the health systems in order to grant their citizens the freedom to fully realize objectives and ambitions, because the higher purpose of a healthcare service is to offer its users the best opportunities to choose the life they desire. In this view, it is useful to refer to the capability approach, a tool to evaluate the wellbeing of people and the social policies aimed at implementing it. According to this approach, development is not intended as financial growth, but rather as human progress, the realization of which cannot overlook fundamental elements such as freedom, wellbeing and health. The capability approach applied to health allows the identification of the higher purpose of a healthcare system, confirming the relevance of the healthcare policies as the foundation on which lies the commitment of the Governments to grant dignity for all citizens. This is why the success of a healthcare service (tab. 1), together with the measurement through classifications and indicators, must be evaluated also on the basis of the freedom that our state of health allows us in order to choose the life we wish to live. (Previtali, 2018; Bloomberg, 2020).

Table 1: Index of the level of assistance per population, year 2020.Source: Bloomberg 2020, Healthiest Country index.

\begin{tabular}{|l|l|l|l|}
\hline Rank & Country & $\begin{array}{l}\text { Health } \\
\text { Grade }\end{array}$ & $\begin{array}{l}\text { Population } \\
\mathbf{2 0 2 0}\end{array}$ \\
\hline $\mathbf{1}$ & Spain & 92.75 & 46.754 .778 \\
\hline $\mathbf{2}$ & Italy & 91.59 & 60.461 .826 \\
\hline $\mathbf{3}$ & Iceland & 91.44 & 341.243 \\
\hline $\mathbf{4}$ & Japan & 91.38 & 126.476 .461 \\
\hline $\mathbf{5}$ & Switzerland & 90.93 & 8.654 .622 \\
\hline $\mathbf{6}$ & Sweden & 90.24 & 10.099 .265 \\
\hline $\mathbf{7}$ & Australia & 89.75 & 25.499 .884 \\
\hline $\mathbf{8}$ & Singapore & 89.29 & 5.850 .342 \\
\hline $\mathbf{9}$ & Norway & 89.09 & 5.421 .241 \\
\hline $\mathbf{1 0}$ & Israel & 88.15 & 8.655 .535 \\
\hline $\mathbf{1 1}$ & Luxemburg & 87.39 & 625.978 \\
\hline $\mathbf{1 2}$ & France & 86.94 & 65.273 .511 \\
\hline $\mathbf{1 3}$ & Austria & 86.3 & 9.006 .398 \\
\hline $\mathbf{1 4}$ & Finland & 85.89 & 5.540 .720 \\
\hline $\mathbf{1 5}$ & Netherland & 85.86 & 17.134 .872 \\
\hline $\mathbf{1 6}$ & Canada & 85.7 & 37.742 .154 \\
\hline $\mathbf{1 7}$ & South Korea & 85.41 & 51.269 .185 \\
\hline $\mathbf{1 8}$ & New Zealand & 85.06 & 4.822 .233 \\
\hline $\mathbf{1 9}$ & United Kingdom & 84.28 & 67.866 .011 \\
\hline $\mathbf{2 0}$ & Ireland & 84.06 & 4.937 .786 \\
\hline $\mathbf{2 1}$ & Cyprus & 83.58 & 1.207 .359 \\
\hline $\mathbf{2 2}$ & Portugal & 83.1 & 10.196 .709 \\
\hline $\mathbf{2 3}$ & Germany & 83.06 & 83.783 .942 \\
\hline $\mathbf{2 4}$ & Slovenia & 82.72 & 2.078 .938 \\
\hline $\mathbf{2 5}$ & Denmark & 82.69 & 5.792 .202 \\
\hline $\mathbf{2 6}$ & Greece & 82.29 & 10.423 .054 \\
\hline $\mathbf{2 7}$ & Malta & 81.7 & 441.543 \\
\hline $\mathbf{2 8}$ & Belgium & 80.46 & 11.589 .623 \\
\hline $\mathbf{2 9}$ & Czech Republic & 77.59 & 10.708 .981 \\
\hline $\mathbf{3 0}$ & Cuba & 74.66 & 11.326 .616 \\
\hline $\mathbf{3 1}$ & Croatia & 73.36 & 4.105 .267 \\
\hline $\mathbf{3 2}$ & Estonia & 73.32 & 1.326 .535 \\
\hline $\mathbf{3 3}$ & Costa Rica & 73.21 & 5.094 .118 \\
\hline $\mathbf{3 4}$ & Chile & 73.21 & 19.116 .201 \\
\hline $\mathbf{3 5}$ & United States & 73.02 & 331.002 .651 \\
\hline $\mathbf{3 6}$ & Bahrain & 72.31 & 1.701 .575 \\
\hline $\mathbf{3 7}$ & Qatar & 71.97 & 2.881 .053 \\
\hline $\mathbf{3 8}$ & Maldives & 70.95 & 540.544 \\
\hline $\mathbf{3 9}$ & Lebanon & 70.53 & 6.825 .445 \\
\hline & & & \\
\hline
\end{tabular}




\begin{tabular}{|l|l|l|l|}
\hline $\mathbf{4 0}$ & Poland & 70.25 & 37.846 .611 \\
\hline $\mathbf{4 1}$ & Montenegro & 69.69 & 628.066 \\
\hline $\mathbf{4 2}$ & Bosnia and Herzegovina & 69.66 & 3.280 .819 \\
\hline $\mathbf{4 3}$ & Albania & 68.04 & 2.877 .797 \\
\hline $\mathbf{4 4}$ & Brunei & 67.96 & 437.479 \\
\hline $\mathbf{4 5}$ & Slovakia & 67.28 & 5.459 .642 \\
\hline $\mathbf{4 6}$ & United Arab Emirates & 67.14 & 9.890 .402 \\
\hline $\mathbf{4 7}$ & Uruguay & 65.66 & 3.473 .730 \\
\hline $\mathbf{4 8}$ & Hungary & 64.43 & 9.660 .351 \\
\hline $\mathbf{4 9}$ & Oman & 64.07 & 5.106 .626 \\
\hline $\mathbf{5 0}$ & Panama & 64.01 & 4.314 .767 \\
\hline $\mathbf{5 1}$ & Turkey & 62.81 & 84.339 .067 \\
\hline $\mathbf{5 2}$ & China & 62.52 & 1.439 .323 .776 \\
\hline $\mathbf{5 3}$ & Mexico & 62.09 & 128.932 .753 \\
\hline $\mathbf{5 4}$ & Argentina & 61.19 & 45.195 .774 \\
\hline $\mathbf{5 5}$ & Serbia & 60.99 & 8.737 .371 \\
\hline
\end{tabular}

We all have the duty to protect the S.S.N., each of us according to their responsibilities, both public and private, cementing a new generational agreement, to pass down to our children the most valuable inheritance: a public, universalistic, and equal healthcare service.

In this context must be considered diseases characterized by the length of the healthcare assistance journeys and the high complexities in terms of treatment and complications (for example, the treatment of a patient infected with Covid19). Such diseases have relevance in epidemiological terms, but also in terms of employed resources and improvement potential from the point of view of the intervention policies, of the public healthcare offer and of the efficiency. (AA.VV., 2014).

The above may refer to the healthcare emergency still in place following the spread of the COVID-19 virus, which is harshly testing the endurance of the National Healthcare Services, employing an enormous amount of resources from both a human and a financial point of view (Comite, 2020).

This work considers the application of the quality of the healthcare assistance profile, trying to obtain a full frame work related to the resources employed across the entire management journey of the emergency to the purpose of understanding the necessary information in order to set up activity improvement policies. The analysis, combining theoretical considerations and empirical evidence related to the treatment of COVID-19, develops the approach described within a complex process of creation of a more efficient and effective healthcare assistance plan.

The COVID-19 pandemic is an exogenous shock for almost the entire world, hitting countries unevenly in terms of citizens' health. They have been exposed to the virus at various times and have different numbers of cases and case fatality rates. European countries have yet to experience such an epidemiological picture and have therefore responded to the COVID-19 outbreak at varying speeds and with policy measures of different severity. If the shock had been symmetrical, joint action at the EU level could probably have been seen. In general, such asymmetries may create a range of institutional, economic, and political challenges that undermine the EU's stability and the effectiveness of the various containment measures. Consequently, differences in the steps taken by European countries may have exacerbated the losses caused by the health asymmetries of the crisis.

According to the WHO, member states are encouraged to develop flexible plans to manage the health risks from pandemic influenza based on a national risk assessment that considers the global risk assessment conducted by the WHO (WHO, 2020).

To contribute to what is currently known about the COVID-19 pandemic, this paperdiscusses the link between fatality rates and the stringency of the most common containment measures being implemented in the EU and the United Kingdom. Although all countries in Europe, except for Sweden, have taken a wide variety of prevention measures, our study focuses on the most imposing decisions that bring social interaction to a complete halt as the most effective way of stemming the spread of COVID-19 (Anderson et al, 2020; McNeil et al, 2020). By determining any links between the stringency of the measures applied and the fatality rates, we aimed to explore ways in which the results could be of value in future health emergency responses at the national/international level. 
Generating information based on real data for and especially during pandemic outbreaks is crucial for supporting governments and international organisations in their public health decision-making (Barsanti, Nuti, 2014; Birley, 2011; Boeckxstaens et al. 2011).

\section{Theoretical and methodological prerequisites of the healthcare assistance profiles}

The Healthcare authorities are highly complex, they manage relevant resources (human, instrumental and financial) guaranteeing heterogeneous and advanced services. In this context, healthcare professionals play a key role since the quality of the services provided is a function of their skills, which can be classified as follows: specialist-professional deriving from university and post-graduate training, implemented by experiences in the clinical-care processes, and managerial-organizational result of everyday life and specific training activities (Osservatorio Nazionale sulla Salute nelle Regioni Italiane, 2017).

An important aspect is the sectorial nature of the functionally specialized health system (Anselmi, 1990, 1996; Borgonovi, 2013). If this guarantees relative ease in obtaining services, given the high distribution of the supply points throughout the territory, the appropriateness of the services frequently does not reach adequate levels. Communication between the various intervention areas is often poor and the path followed by the patient extemporaneously presents adequate levels of integration (Foglietta, 2020).

A further element lies in the identification of interdependencies between activities and processes to activate adequate controls or proceed with the redesign, improving coordination in terms of quality, quantity and time (Del Bene, 2000; Marinò, 2001).

Despite the growing sectorialization of knowledge, the satisfaction of a health need often implies, consistently with the organization of the NHS, the participation of multiple units and professionals, fragmenting the care process through which the patient obtains the services necessary to give an exhaustive response. to your needs.

The ensuing governance difficulties cause delays in obtaining performance, duplication of operations, expansion of processes due to the circuit in which the patient is involved, passing from one unit to another, resulting in the S.S.N. an economic-financial burden due to the inorganic nature existing between the units, often creating oversized structures compared to real needs (Borgonovi, 2013).

In this regard, literature has for some time highlighted the possibility of applying process management to these contexts (Manganelli, Klein, 1995; Merli, Biroli, 1996; Hammer, Champy, 1995), which health has found multiple applications related to care profiles and/or "care pathways" (Carmichael, 1994; Griffit, 1994; Zimmermann, 1994; Casati, 1999), resulting in a subject in progress relative to the various situations in which it is applied. In this sense, it is possible to evaluate the results of organizational areas that include operational units falling within the scope of homogeneous activities (e.g. the Department of Surgery, or the Anesthesia and Resuscitation Unit - Intensive Care, belonging to the Emergency Department), or of transmural aggregations coordinating activities related to UO upstream and downstream of a supply process, located in the area and in hospitals.

The approach can be based on an external orientation, where the analysis takes place by designing the processes starting from the demand, highlighting those deemed necessary to meet the needs posed; they will then be classified into primary support or managerial according to the role assumed, or internal, according to which the processes are identified starting from the existing organizational structure. It will be a question of checking the activities carried out within the various organizational units aimed at treating the pathology in question. As part of the research, an integrated analysis was chosen, carrying out a check of the activities carried out in the various organizational units aimed at treating COVID-19. Once the cognitive phase of the current situation is completed, relating to the company's response methods to needs, it will be necessary to design (or re-design) the care path, eliminating or mitigating the critical issues. The design of a new path should centrally place the needs of the patients around whom the diagnostictherapeutic-assistance process unfolds (Comite, 2020). The patient becomes fundamental by often assuming an active role in the course (Normann, 1992, Borgonovi, 2012), while providing for compliance with standards and prescriptions (Baccarani, Ugolini, 2000). The sharing of knowledge and the path become essential for the operators involved to adapt their behavior to the common needs of the team.

In summary, while respecting professional autonomy, the actors involved homogenize the approach to problems consistently with what is established at the process level.

In the design phase (or re-design), the professionals involved are encouraged to seek alternative solutions that can improve the methods of use of the services necessary for the patient in terms of time, accessibility, obviously without 
neglecting the possibility, all other conditions being equal, to rationalize the use of resources, all together with the constant presence of the company management in continuously supporting the initiative.

\section{The COVID-19 health emergency: background information}

The novel coronavirus disease (COVID-19), caused by the virus named SARS-CoV-2 (previously 2019-nCoV), is a highly infectious disease (Chen et al, 2020; Zhu et al, 2020) and, due to the rapid increase in the number of cases from December 2019, it was classified by the World Health Organization (WHO) as a pandemic on March 11, 2020 (Wang et al, 2020).

Specifically, in late December 2019, Chinese doctors highlighted clusters of patients with pneumonia of unknown cause, epidemiologically linked to a wholesale market in Wuhan, Hubei Province ( $\mathrm{Zu}$ et al, 2020; Yan et al, 2020). The situation became so critical that, on December 31, 2019, the Chinese Center for Disease Control and Prevention promoted an epidemiologic investigation on this new disease.

It has emerged that the traditional public health measures similar to those adopted in 2003 to curb the outbreak of severe acute respiratory syndrome (SARS), such as syndromic surveillance, the prompt isolation of patients, and enforced quarantine, are less effective with SARS-CoV-2, and, above all, we have learned that containment measures must be strict and broad, and not loosened too early.

Despite the security and mitigation measures taken by the Chinese government, including quarantine in Hubei Province, infections spread across China and, today, it has affected more than 200 countries worldwide (Bordi et al, 2020; Holshue et al, 2020). Consequently, on January 30, 2020, the WHO declared this outbreak a Public Health Emergency of International Concern (PHEIC) (Wang et al, 2020).

The public perception of biological hazard plays a key role in the response to health emergencies, affecting risk management and risk communication strategies (Slovic, 1987; Slovic, 2000). Therefore, the public perception of health risks can influence markets, public policies, and individual behaviors (Krewski, 1995).

In the last decades, many countries have been implemented policies to cut public spending. As a consequence, despite the United Nations have stressed the necessity to strengthen health resilience (UNDRR, 2015), the investment in public health systems have decreased (Garrett, 2000; Smith, 2009), increasing vulnerability and exacerbating the negative effects of this pandemic (Alexander et al, 2019).

Another factor affecting the rapid worldwide spread of the SARS-CoV-2 is related to the difficulty in detecting infected people because of the lack of symptoms, as well as to similarities with symptoms of common cold and flu (Yan et al, 2020; Chan et al, 2020).

As reported during other similar health emergencies (Lindell et al., 2007), decision makers at international, national, regional, and local levels should implement strict and unpopular public health measures to prevent and reduce the biological risk consequent to the virus spread, such as lockdown and quarantine. These measures are focused on slowing the outbreak spread and reducing the peak healthcare demand, with the scope of flattening the infection curve and reducing the peak of the outbreak (Cowling, 2020; Wilder, 2020). Moreover, these actions attempt to protect, as in this case, those people who are most at risk of severe disease from infection, in particular those with chronic health conditions and older people (Wang et al., 2020; Zhou et al., 2020). However, the radical change in daily habits, the limitation of social life and the stress resulting from the public health emergency could have a strong impact on the well-being of individuals (Brooks et al., 2020; Zhang et al., 2020).

As highlighted by the WHO during the spreading of the first coronavirus (WHO, 2015), the SARS-CoV-2 emergency represents a major global public health threat which requires a coordinated global response. However, there is a general interest towards the promotion of public health measures at individual and local scales to prevent disease rather than common public health actions (Vineis, 2014; Vineis, 2017). In particular, the lack of coordinated responses among the governments of countries involved in this public-health emergency has been observed both in terms of response time and adopted actions. This might be due to the creeping nature of this kind of hazard, which begins to concern only when the negative effects of the trigger factor become visible and tangible and the emergency could already have reached the critical transition, shifting in a cascading disaster (Pescaroli et al., 2015; Scheffer, 2009). As an example of the uncoordinated responses, even if the Chinese government applied draconian mitigation measures in the worstaffected areas from January 23, 2020, in the EU, UK, and USA, it was necessary to wait at least one month to see similar containment measures applied. 
Generally, some cross-cutting aspects, such as communication, stakeholder engagement and context, are fundamental in order to cope with hazards and risks in situation of high complexity, uncertainty, and ambiguity (Alexander, 2002; IRGC, 2017). As argued by Slovic (Slovic, 2000; Krewski, 1995), those who assess and manage public health and safety should deeply investigate the way in which people perceive and face with risks.

As a matter of fact, most of people who face hazardous phenomena rely on intuitive risk evaluation, so called risk perception, which is unavoidably influenced by both mass media and social contacts with friends, relatives, and colleagues (Short, 1984). With regard to the influence of mass media, it is important to stress their role in public perception of health risk, inasmuch they often give information mainly focused on mishaps and threats occurring in affected countries (Slovic, 2000). Since people usually make decisions based on their risk perception rather than the effective risk (Slovic, 1987), public perception of health risk plays a key role in the adoption of measures, in their acceptance, in the feelings of the population, and in the decisions that people will take.

Decision makers, who are usually prone to act according to the effective risk (Smith, 2006), should consider public perception of health risk, as well as its communication for an effective emergency and risk management (Alexander, 2002). Moreover, risk management and communication need to be structured considering both public perception of health risk and experts contributions as a two-way process, otherwise efforts to manage public emergencies risk to fail (Slovic, 2000).

In particular, the public underestimation of health risk might reduce the acceptance of the strict mitigation measures enforced by governments (Alexander, 2000). On the contrary, some feelings, such as fear and anxiety, are more likely to cause overestimation of the health risk (Tripp et al., 1995; Goodall et al., 2012). Notably, previous studies suggest that the spread of a virus can contribute to a widespread sense of panic and concern in the community (Goodall et al., 2012; Lau et al., 2010). The perception of the level of lethality of a virus seems, in fact, to be associated

with the development of emotional distress (Lau et al., 2010; Wang et al., 2020), which involves the need to structure psychological assistance interventions (Braunack-Mayer et al., 2010). Moreover, at list in the short term, social media may affect feelings and, consequently, risk perception (AfWahlberg et al., 2000). Consequently, the information provided by the media and other official sources, as well as the way in which they are communicated, play a key role during these emergencies (Falagas et al., 2006).

China had faced five pandemics in the last century, three of which originated in China, namely the "Asian flu" (1957), the "Hong Kong flu" (1968), and the "Russian flu" (1977) (Qin et al, 2018). These experiences have made the country able to react relatively quickly and effectively. However, when the disease appeared en masse in Europe, both the health profession and governments were quite unprepared.

This was especially evident in Italy, one of the first countries in Europe with a large number of infected. As the number of infected grew exponentially after 21 February, the capacity of the public health system was soon under pressure. Public health measures and their level of severity at the start of the outbreak were considerably different to those adopted in China, seeing cases skyrocket (Remuzzi et al, 2020). In Italy, approximately $40 \%$ of cases required hospitalisation, whereas in China, the reported numbers are considerably lower (15\%-20\%) (Lazzerini et al, 2020; Wu et al, 2020). The variability in acute and critical care bed numbers across Europe is considerable. The number of critical care beds per 100,000 population ranges from 4.2 in Portugal to 29.2 in Germany, with 6.6 in the United Kingdom, 9.7 in France, and 12.5 in Italy. The number of doctors per 1000 population ranges from 1.9 in Turkey to 5.2 in Austria, while the need for critical care capacity is continually rising.

The increase in demand is particularly problematic in times of quick and unexpected events, where healthcare and the supporting system have no time to accommodate. When the population is old, like in Italy - which has the oldest population in Europe and the second oldest in the world, with 23 percent of older adults (65+) and a life expectancy at birth that amounts to 81 years for men and 85.3 years for women (Ministero della Salute, 2020; Statista Life, 2020) - a disaster is likely to occur (Protezione Civile, 2020). The success of public health measures to curb the transmission of the virus is a critical step in reducing the surge-capacity needs. Therefore, to plan for changes in a timely manner, we need to better understand the current situation in each country and its policy responses in past pandemics and the current one. It is only with a combination of an effective set of policies that are suitably aligned that we will be able to successfully respond to outbreaks.

\section{Material and methods for the analysis}

The data for the analysis were obtained from the Oxford COVID-19 Government Response Tracker (Blavatnik School of Government, 2020), which collects publicly available information on a set of indicators of government responses; 
POLITICO, a policy news organisation (POLITICO, 2020); and Worldometer for the number of deaths per 1,000,000 population on 15 April 2020 (Worldometer, 2020). The cut-off date for the data on containment measures is 1 April 2020, a date when European countries reached peak values on the stringency index that records the number and strictness of government policies, published by Hale and his colleagues (Hale et al., 2020). Our study explores the adoption of containment measures in 24 European Union member states and the UK (Table 2).

Table 2: A list of countries with the corresponding country codes included in the study. Source: pers. proc.

For a detailed description of the measures by countries, see Appendix.

\begin{tabular}{ll} 
Country Name & Country Code \\
\hline Austria & AT \\
Belgium & BE \\
Bulgaria & BG \\
Croatia & HR \\
Cyprus & CY \\
CzechRep. & CZ \\
Denmark & DK \\
Estonia & EE \\
Finland & FI \\
France & FR \\
Germany & DE \\
Greece & EL \\
Hungary & HU \\
Ireland & IE \\
Italy & IT \\
Luxembourg & LU \\
Netherlands & NL \\
Poland & PL \\
Portugal & PT \\
Romania & RO \\
Slovakia & SK \\
Slovenia & SI \\
Spain & ES \\
Sweden & SE \\
UnitedKingdom & UK \\
\hline
\end{tabular}

For a detailed description of the measures by countries, see Appendix. 
This study adopts a crisp-set qualitative comparative analysis (csQCA) approach. csQCA is a common QCA technique used in the case of categorical variables to identify multiple causal pathways and derive logical conclusions supported by a data set.

One key operation of the csQCA is Boolean minimisation to reduce complex expressions into more parsimonious expressions (Rihoux, 2009). The obtained minimal formula allows an easier interpretation of the phenomenon of interest, which in our study is fatality in relation to the measures taken, and thus clearly shows what is common to all countries that share above-median or below-median death rates. The conditions (i.e., measures) and an outcome (i.e., fatality rate) are codified and described in Table 3.

Table 3: Coding and describing the conditions and outcomes. Source: pers. proc.

\begin{tabular}{|c|c|c|c|}
\hline Condition/Outcome & & Codification & Description \\
\hline $\begin{array}{l}\text { Above-median } \\
\text { (outcome) }\end{array}$ & deaths & AMD & $1=$ more than 44 deaths per $1,000,000$ population \\
\hline $\begin{array}{l}\text { Below-median } \\
\text { (outcome) }\end{array}$ & deaths & BMD & $0=$ less than 44 deaths per $1,000,000$ population \\
\hline Speed of response & & TIMING & $\begin{array}{l}0=\text { first measure (school closure or public event } \\
\text { cancellation) taken after first death, } 1=\text { first } \\
\text { measure } \\
\text { taken before first death }\end{array}$ \\
\hline State of emergency & & EMERGENCY & $0=$ no, $1=$ yes \\
\hline Borders and travel & & BORDERS & $0=$ restrictions, $1=$ closed $/$ banned \\
\hline International flights & & FLIGHTS & $0=$ restricted, $1=$ suspended \\
\hline Lockdown & & LOCKDOWN & $0=$ no/partial lockdown, $1=$ yes \\
\hline
\end{tabular}

All possible combinations of conditions (technically known as configurations) for which empirical evidence exists are presented in Table 4. The present study includes five conditions, leading to 25 configurations. To illustrate, Row 15 represents European countries that share the following set of conditions: national lockdown, emergency state declared, restrictions on borders, restricted international flights, and first measures taken after the first deaths. All countries (Spain, Italy, and France) in this set have above-median levels of death.

The following section presents the results of an analysis of necessity and sufficiency to help determine the conditions required for the outcome (analysis of necessity), and which combination of conditions produces which outcomes (analysis of sufficiency) (Rihoux et al, 2012). To perform these analyses, we used the fsQCA 2.5 software (Ragin et al, 2009). To assess how well the cases in the data set fit a relation of necessity and suffciency, we report the following parameters of fit: consistency and coverage. If consistency or coverage scores for the solution are low (below 0.75), this signals a badly specified model (Legewie, 2013).

Table 4: truth table. Source: pers. proc.

\begin{tabular}{|c|c|c|c|c|c|c|c|c|}
\hline \multicolumn{6}{|c|}{ Row Conditions } & \multirow[t]{2}{*}{$n^{\circ}$ of cases } & \multirow{2}{*}{$\begin{array}{r}R \\
\text { Cons } \\
\text { (ou }\end{array}$} & \multirow{2}{*}{$\begin{array}{c}\text { Raw } \\
\text { onsistency } \\
\text { (outcome) }\end{array}$} \\
\hline & Lockdown & Emergency & Borders & Flights & Timing & & & \\
\hline 1 & 0 & 1 & 0 & 1 & 0 & 1 & LU & $100 \%(1)$ \\
\hline 2 & 0 & 1 & 1 & 1 & 1 & 2 & SK, DK & $50 \%$ \\
\hline 3 & 1 & 1 & 0 & 1 & 1 & 1 & BG & $100 \%(0)$ \\
\hline 4 & 1 & 0 & 1 & 1 & 1 & 2 & PL, CY & $100 \%(0)$ \\
\hline 5 & 0 & 0 & 0 & 1 & 1 & 1 & HR & $100 \%(0)$ \\
\hline 6 & 0 & 1 & 1 & 0 & 1 & 1 & $\mathrm{HU}$ & $100 \%(0)$ \\
\hline 7 & 1 & 1 & 1 & 0 & 1 & 1 & FI & $100 \%(0)$ \\
\hline 8 & 1 & 0 & 0 & 0 & 1 & 2 & $\mathrm{EL}, \mathrm{AT}^{1}$ & $100 \%(0)$ \\
\hline 9 & 1 & 1 & 1 & 1 & 1 & 1 & $\mathrm{CZ}$ & $100 \%(0)$ \\
\hline 10 & 1 & 1 & 0 & 0 & 1 & 2 & $\mathrm{RO}, \mathrm{PT}$ & $50 \%$ \\
\hline 11 & 1 & 0 & 0 & 1 & 1 & 1 & SI & $100 \%(0)$ \\
\hline 12 & 0 & 0 & 1 & 0 & 0 & 1 & $\mathrm{DE}$ & $100 \%(0)$ \\
\hline 13 & 1 & 0 & 0 & 0 & 0 & 3 & IE, NL, UK & $100 \%(1)$ \\
\hline 14 & 0 & 0 & 0 & 0 & 0 & 1 & SE & $100 \%(1)$ \\
\hline 15 & 1 & 1 & 0 & 0 & 0 & 3 & FR, IT, ES & $100 \%(1)$ \\
\hline 16 & 1 & 0 & 1 & 0 & 0 & 1 & $\mathrm{BE}$ & $100 \%(1)$ \\
\hline 17 & 0 & 1 & 0 & 1 & 1 & 1 & $\mathrm{EE}$ & $100 \%(0)$ \\
\hline
\end{tabular}


Note: The rows use the following labelling system: $1=$ set membership, $0=$ no set membership. Since they do not add empirical evidence, rows 25-17 are not shown in the above table. 1 Austria is a country with a median death rate. The decision to place it in the group of member states with below-median deaths (BMD) is due to the fact that the number of deaths in Austria is below the average in the observed countries (98 deaths/1 million population).

\section{Results}

The first part of the analysis is intended to examine the existence of necessary conditions. When the value for consistency exceeds 0.9 and the coverage is greater than 0.5, a condition is regarded as necessary (Schneider et al, 2012). A test of necessity reveals that the presence of TIMING is necessary for below-median deaths (Table 5).

Table 5: individual conditions: test of necessity. Source: pers. proc.

\begin{tabular}{ccc} 
Condition & Above-Median Deaths & Consistency for Belw-Median Deaths \\
\hline LOCKDOWN & 0.67 & 0.69 \\
EMERGENCY & 0.50 & 0.54 \\
BORDERS & 0.25 & 0.46 \\
FLIGHTS & 0.17 & 0.80 \\
TIMING & 0.171 & 1 (cov.: 0.87$)$ \\
lockdown & 0.33 & 0.31 \\
emergency & 0.50 & 0.46 \\
borders & 0.75 & 0.54 \\
flights & 0.83 & 0.33 \\
timing & 0.83 & 0.00 \\
\hline
\end{tabular}

Note: Capital letters denote the condition's presence; lower-case ones point to the condition's absence.

Table 6 shows the results for the combination of conditions associated with above-median deaths. The csQCA generated three complex solutions. The analysis clearly shows that all three configurations include the condition of the late introduction of the first quarantine measures (TIMING). According to the first minimal part of the formula (AMD1), a late response, an undeclared state of emergency, and restricted - but not suspended - international flights led to above-median deaths (the presence orabsence of the conditions LOCKDOWN and BORDERS are irrelevant for this configuration). These are Germany, Belgium, Sweden, the UK, the Netherlands, and Ireland. In the next solution, AMD2, one finds countries that share a late response, national lockdown, restricted international flights, and restrictions on borders (the condition EMERGENCY is redundant for this solution to emerge).

Representatives of this configuration are France, Italy, and Spain. For three countries, namely Ireland, the UK, and the Netherlands, both paths are valid. This combination of conditions is seen in countries with the highest fatality rates. Similarly to AMD1, this implies that the countries opted for less stringent measures to combat COVID-19. The only stringent measure in these two reduced expressions is national lockdown. The third solution, AMD3, covers the case of Luxembourg with two stringent measures - a declared state of emergency and stopping international flights, but coupled with a late response, partial lockdowns, and restrictions on borders.

To examine which set of conditions leads to below-median deaths (Table 7), we performed a separate analysis of suffciency. Four alternative paths lead to the outcome. The first two cover most cases. The cases in BMD1 all share an early response, stopped international flights, and restrictions on borders. This combination corresponds to Bulgaria, Croatia, Slovenia, and Estonia. The second configuration combines an early response, national lockdown, and stopped international flights

(Bulgaria, Poland, Czech Republic, Slovenia, and Cyprus). The other two solutions are composed of an early response, national lockdowns put in place, an undeclared state of emergency, and restrictions on borders (BMD3); and an early response, a declared state of emergency, closed borders, and restricted international flights (BMD4). Solution BMD3 is specific to Greece, Austria, and Slovenia, while solution BMD4 corresponds to Hungary and Finland.

According to our expectations, an early response is common to all countries in the set of below-median deaths. Likewise, the suspension of international flights is seen in many countries in the set of BMD. The results also imply that these countries implemented more stringent measures compared to those facing above-median and severe deaths. In terms of redundant conditions, the state of emergency does not play a role in configurations BMD1 and BMD2; likewise, the LOCKDOWN condition has no role in BMD1 and BMD4. 
Table 6: configurations for above-median deaths (AMD) with a consistency cut-off of 1 . Source: pers. proc.

\begin{tabular}{|c|c|c|c|}
\hline \multirow[t]{2}{*}{ Condition } & \multicolumn{3}{|c|}{ Configuration } \\
\hline & AMD1 & AMD2 & AMD3 \\
\hline TIMING & $\mathrm{X}$ & $\mathrm{X}$ & $\mathrm{X}$ \\
\hline LOCKDOWN & & * & $\mathrm{X}$ \\
\hline EMERGENCY & $\mathrm{X}$ & & $*$ \\
\hline BORDERS & & $\mathrm{X}$ & $\mathrm{X}$ \\
\hline FLIGHTS & $\mathrm{X}$ & $\mathrm{X}$ & $*$ \\
\hline Consistency & 1 & 1 & 1 \\
\hline Raw coverage & 0,50 & 0,50 & 0,08 \\
\hline Unique coverage & 0,25 & 0,25 & 0,08 \\
\hline $\begin{array}{l}\text { Solution } \\
\text { consistency }+\end{array}$ & \multirow{2}{*}{\multicolumn{3}{|c|}{$\begin{array}{c}1 \\
0,83\end{array}$}} \\
\hline $\begin{array}{l}\text { Solution coverage } \\
\#\end{array}$ & & & \\
\hline
\end{tabular}

Note: * condition (present); x condition (absent); blank spaces mean "do not care". + Solution consistency: the accuracy of the approximation of the perfect subset relation. \# Solution coverage: the proportion of cases that are covered by all of the terms.

Table 7: configurations for belowe-median deaths (AMD) with a consistency cut-off of 1 . Source: pers. proc.

\begin{tabular}{|c|c|c|c|c|}
\hline \multirow[t]{2}{*}{ Condition } & \multicolumn{4}{|c|}{ Configuration } \\
\hline & BMD1 & BMD2 & BMD3 & BMD4 \\
\hline TIMING & $*$ & $*$ & $*$ & $*$ \\
\hline LOCKDOWN & & $*$ & $*$ & \\
\hline EMERGENCY & & & $\mathbf{X}$ & \\
\hline BORDERS & $\mathrm{X}$ & & $\mathrm{X}$ & $*$ \\
\hline FLIGHTS & * & * & & $\mathbf{X}$ \\
\hline Consistency & 1 & 1 & 1 & 1 \\
\hline Raw coverage & 0,31 & 0,38 & 0,23 & 0,15 \\
\hline $\begin{array}{l}\text { Unique } \\
\text { coverage }\end{array}$ & 0,15 & 0,23 & 0,15 & 0,15 \\
\hline $\begin{array}{l}\text { Solution } \\
\text { consistency + }\end{array}$ & \multirow{2}{*}{\multicolumn{4}{|c|}{0,85}} \\
\hline $\begin{array}{l}\text { Solution } \\
\text { coverage \# }\end{array}$ & & & & \\
\hline
\end{tabular}

Note: * condition (present); x condition (absent); blank spaces mean "do not care". + Solution consistency: the accuracy of the approximation of the perfect subset relation. \# Solution coverage: the proportion of cases that are covered by all of the terms.

\section{Discussion and conclusion}

In this study, we conducted an analysis to help understand how the responses of individual EU member states and UK are linked to the fatality rates caused by SARS-CoV-2. csQCA minimal formulas allow us to focus on the "ingredients" producing (or not) an outcome of interest, with an eye on within-case narratives and cross-case patterns (Rihoux et al, 2009). Our results imply that no single combination of conditions leads to the outcome of non-high or high fatalities related to the disease. In other words, more than one combination of measures leads to either outcome. If a similar situation were to occur in the future (also including repeated waves of the virus), it would be beneficial to have all the information available from past experiences to respond as effectively as possible. This explains the important need to investigate this extreme health phenomenon from a policy perspective, promptly, spatially, broadly, and in depth, allowing for the specifics of countries and their different responses.

Depending on how they assessed the severity and magnitude of the coronavirus' presence in the country, many governments decided to declare a state of emergency to unlock certain government powers to deal with the pandemic. 
However, this measure is present and absent in both outcomes; namely, in the sets ofcountries with above-median fatality rates and below-median ones. Therefore, our results imply that a state of emergency can bring about different outcomes based on how it is combined with other causal conditions. The same applies to the national lockdown measure since this condition is present in two of the four paths leading to the BMD outcome and in one path leading to AMD. On the other hand, the roles of closed borders and restrictions on borders in fighting the COVID-19 pandemic remain unclear. A core condition for below-median fatality rates seems to be a quick response because this condition is present in all BMD paths. In Europe, the adoption of measures before the first deaths was a characteristic of Central and Eastern European countries and Finland. Their decisions were most likely based on the experiences of other European countries that were first exposed to the outbreak.

By contrast, countries in the set with above-median fatality rates are characterised by a late response. This set contains countries with an older population with at least one other health condition (asthma, chronic obstructive pulmonary disease, diabetes, and heart problems) in Europe, while the association with smoking patterns is uncertain.

Moreover, the many interactions and trade-offs between containment measures significantly add complexity to the decision-making on combatting the COVID-19 pandemic. For example, suspending international flights is a prerequisite in two configurations related to below-median deaths (BMD1 and BMD2). By the same token, the restriction of only (but not suspended) international flights is present in two configurations leading to above-median deaths (AMD1 and AMD2). In configuration BMD4, in which only international flights were restricted, the countries (Hungary and Finland) seem to have compensated for the outcome of this decision by closing their borders quickly enough to appear in the set of countries with below-median fatalities. Therefore, we may conclude that the decision to suspend international flights might be critical in successful virus control.

The biggest challenge in decision-making in health risk prevention is to strike a balance between reducing the risk of viral transmission and the economic costs, through the sustainable development goals (Anderson et al, 2020; Gong et al, 2020). Given the varying death statistics in individualmember states, itmay be argued that the COVID-19 pandemic is an asymmetric health shock.

Still, the global socioeconomic disruption suggests a symmetrical shock at the economic level. The EU is expected to act quickly and together to prevent the crisis from becoming a long-term demand-side crisis, which would signal its deepening and transformation into a structural one. Especially in the area of public health, we expect that globalisation will prevent any achievement of the pre-crisis level and thus restructuring will occur. For example, health diagnostics and medical treatments performed in other countries have been completely interrupted during the pandemic. Once the situation returns to normal, quarantine will probably still be required before referring a patient abroad and after a patient comes home. International medical treatment will therefore slow down, and health professionals fromindividual countries will need to undertake specific specialist training to acquire knowledge and develop skills that are currently lacking in their own country. Moreover, the role of the public healthcare system is expected to be strengthened as experts call for an institutionalised private-public sector partnership for future critical cases such as epidemic emergencies (Armocida et al., 2020).

Future studies could to examine a link between the share of private and public healthcare systems in each country. During the pandemic, we can observe a growing preference for public hospitals (IBIS, 2020).

However, in the most affected regions of Italy, the National Healthcare Service suffered financial cuts, privatisation, and a deprivation of human and technical resources (Armocida et al. 2020; Istituto Superiore di Sanità, 2020).

This unexpected situation is certainly bringing new challenges to our current healthcare systems (Borgonovi et al., 2013).

\section{References}

AA.VV., Standards for equity in health care for migrants and other vulnerable groups. Task Force Migrant Friendly Hospital and Health Services, 2014.

Af Wåhlberg, A., Sjöberg, L., Risk perception and the media, 2000, Journal of Risk Research.

Alexander, D., Confronting Catastrophe: New Perspectives on Natural Disasters; Oxford University Press: Oxford, UK, 2000.

Alexander, D., Principles of Emergency Planning and Management; Oxford University Press: Oxford, UK, 2002.

Alexander, D.A., Pescaroli, G., What are Cascading Disasters? UCL Press: London, UK, 2019.

Anderson, R.M., Heesterbeek, H., Klinkenberg, D., Hollingsworth, T.D., How will country-based mitigation measures influence the course of the COVID-19 epidemic?, 2020, The Lancet.

Anselmi L., L'Azienda pubblica sanitaria, 1990, L'Azienda Salute. 
Anselmi L., L'equilibrio economico nelle aziende sanitarie, Il Sole 24 Ore, Milano, 1996.

Armocida, B., Formenti, B., Ussai, S., Palestra, F., Missoni, E., The Italian health system and the COVID-19 challenge, 2020, The Lancet Public Health.

Baccarani C., Ugolini M., Quality in health service: using patient charter as a management tool, 2000, Paper presented to the International Conference QMED 2000, Aahrus, Denmark.

Barsanti S., Nuti S., The equity lens in the health care performance evaluation system, 2014, The International Journal of health Planning and Management.

Birley M., Health Impact Asessment: principles and practice, NY, Hearthscan, 2011.

Blavatnik School of Government, University of Oxford, 2020. [database] Oxford COVID-19 Government Response Tracker. [online]: https://www.bsg.ox.ac.uk/research/research-projects/oxford-covid-19-governmentresponseTracker, accesed 14 June 2020.

Bloomberg Healthiest Country index, USA, 2020.

Boeckxstaens P., De Smedt D., De Maeseneer J., Annemans L., Willems S., The equity dimension in evaluations of the quality and outcomes framework: A systematic review, BMC Health services research, 11, Biomed Central, UK, 2011.

Bordi, L., Nicastri, E., Scorzolini, L., Di Caro, A., Capobianchi, M.R., Castilletti, C., Lalle, E., Differential diagnosis of illness in patients under investigation for the novel coronavirus (SARS-CoV-2), February 2020, Eurosurveillance, Italy, 2020.

Borgonovi E., Lecci F., Ricci A., Salvatore D., Strumenti di governo per la gestione delle patologie croniche in medicina generale, in AA.VV., Il Sistema Sanitario in controluce, Rapporto 2011, F. Angeli, Milano, 2012.

Borgonovi E., Lecci F., Ricci A., Salvatore D., L'impatto dell'adozione di strumenti di governo clinico sulla risposta assistenziale. Il Sistema Sanitario in controluce. Rapporto 2012. F. Angeli, Milano, in AA.VV 2013, (Fondazione Farmafactoring), Milano, 2013.

Brooks, S.K., Webster, R.K., Smith, L.E., Woodland, L., Wessely, S., Greenberg, N., Rubin, G.J., The psychological impact of quarantine and how to reduce it: Rapid review of the evidence, 2020, The Lancet.

Carmichael B.D., Business process reengineering: a remedely for health care, 1994, Healthcare Management Forum.

Casati G. (a cura di), Il percorso del paziente, Egea, Milano, 1999.

Chan, J.F.W., Yuan, S., Kok, K.H., To, K.K.W., Chu, H., Yang, J., Xing, F., Liu, J., Yip, C.C.Y., Poon, R.W.S., A familial cluster of pneumonia associated with the 2019 novel coronavirus indicating person-toperson transmission: A study of a family cluster, 2020, The Lancet.

Chen, H., Guo, J., Wang, C., Luo, F., Yu, X., Zhang, W., Li, J., Zhao, D., Xu, D., Gong, Q., Clinical characteristics and intrauterine vertical transmission potential of COVID-19 infection in nine pregnant women: $A$ retrospective review of medical records, 2020, The Lancet.

Comite U., Businesses and Public Health between using Lock Down as a Tool against Covid-19 pandemic in Italy: The Impact in a Global Perspective, 2020, Advances in Management, Vol. 13 (2).

Comite U., On the Safety of Treatments, Clinical Risk Management and Patient Well-being in the Pandemic Crisis: Problems and Recommendations due to COVID-19. A Dynamic Analysis of Fatality Risk in Italy, 2020, European Journal of Economics, Finance and Administrative Sciences, Issue 105 June, 2020.

Cowling, B.J., Aiello A., Public health measures to slow community spread of COVID-19, 2020, The Journal of Infectious Diseases.

Del Bene L., Criteri e strumenti per il controllo di gestione nelle aziende sanitarie, Giuffrè, Milano, 2000.

Falagas, M.E., Kiriaze, I.J., Reaction to the threat of influenza pandemic: The mass media and the public, 2006, Critical Care.

Foglietta F. (a cura di), Management in Sanità, Maggioli, Rimini, 2020.

Garrett, L., Betrayal of Trust: The Collapse of Global Public Health, Hyperion: New York, NY, USA, 2000.

Gong, B., Zhang, S., Yuan, L., Chen, K.Z., 2020. A balance act: Minimizing economic loss while controlling novel coronavirus pneumonia, [online] https://www.tandfonline.com/doi/full/10.1080/23812346.2020. 1741940, accessed 14 June 2020.

Goodall, C., Sabo, J., Cline, R., Egbert, N., Threat, Efficacy, and Uncertainty in the First 5 Months of National Print and Electronic News Coverage of the H1N1 Virus, 2012, Journal of Health Communication.

Griffit J.R., Reengineering, healthcare: management system for survivors, Hospital and health services administation, Gavin Publisher, USA, 1994.

Hale, T., Webster, S., Petherick, A., Phillips, T., Kira, B., 2020. Data use policy: Creative commons attribution CC by standard, [online] https://www.bsg.ox.ac.uk/research/research-projects/coronavirusgovernment-responsetracker, accessed on 14 June 2020. 
Hammer M., Champy J., Reengineering the corporation: a manifesto for business revolution, Harpers business, HarperCollins Publishers, UK, 1995.

Holshue, M.L., DeBolt, C., Lindquist, S., Lofy, K.H., Wiesman, J., Bruce, H., Spitters, C., Ericson, K., Wilkerson, S., Tural, A., First Case of 2019 Novel Coronavirus in the United States, 2020, The New England Journal of Medicine.

IBIS, 2020. World Effects of COVID-19 on Global Healthcare Systems, [online] https://www.ibisworld. com/industryinsider/coronavirus-insights/effects-of-covid-19-on-global-healthcare-systems/, accessed on 14 June 2020.

International Risk Governance Council (IRGC), 2017. Introduction to the IRGC Risk Governance Framework; International Risk Governance Council (IRGC): Geneva, Switzerland, 2017, [online] https://irgc.org/riskgovernance/irgc-risk-governance-framework/, Int. J. Environ. Res. Public Health 2019, accessed on 27 April 2020.

Istituto Superiore di Sanità 2020, Sezione Coronavirus, https://www.epicentro.iss.it/coronavirus/, [online], accessed on 14 June 2020.

Krewski, D., Slovic, P., Bartlett, S., Flynn, J., Mertz, C.K., Health risk perception in Canada I: Rating hazards, sources of information and responsibility for health protection, 1995, Human and Ecological Risk Assessment: An International Journal.

Lau, J.T.F., Griffiths, S., Choi, K.C., Tsui, H.Y., Avoidance behaviors and negative psychological responses in the general population in the initial stage of the H1N1 pandemic in Hong Kong, 2010, BMC Infectious Diseases.

Lazzerini, M., Putoto, G., COVID-19 in Italy: Momentous decisions and many uncertainties, 2020, The Lancet Global Health.

Legewie, N., An introduction to applied data analysis with qualitative comparative analysis, 2013, Forum Qualitative Social Research.

Lindell, M.K., Perry, R.W., Prater, C., Introduction to Emergency Management; Wiley: Hoboken, NJ, USA, 2007.

Manganelli R.L., Klein M.M., The reengineering revolution, Harpers business, HarperCollins Publishers, UK, 1993.

Marinò L., Dinamiche competitive ed equilibrio economico nelle aziende sanitarie, Giuffrè, Milano, 2001.

McNeil, D., The Virus Can Be Stopped, but Only With Harsh Steps, Experts Say, 2020, [online] https://www.nytimes.com/2020/03/22/health/coronavirus-restrictions-us.html, accessed on 14 June 2020.

Merli G., Biroli M., Organizzazione e gestione per processi, Isedi, Torino, 1996.

Normann R., La gestione strategica dei servizi, Etas, Milano, 1992.

Osservatorio Nazionale sulla Salute nelle Regioni Italiane, Rapporto Osservasalute 2017, Roma, 2017.

Pescaroli, G., Alexander, D., A definition of cascading disasters and cascading effects: Going beyond the "toppling dominos" metaphor, GRF Davos Planet Risk, 2015.

Politico, 2020. [database] Coronavirus in Europe, [online] https://www.politico.eu/article/europescoronaviruslockdown-measures-compared/, accessed on 14 June 2020.

Previtali P. (a cura di), Management sanitario e governance della complessità, Pavia University Press, Pavia, 2018.

Protezione Civile, Presidenza del Consiglio dei Ministri 2020. Dipartimento della protezione Civile, Sezione Coronavirus, [online]

http://www.protezionecivile.gov.it/attivita-rischi/rischio-sanitario/emergenze/coronavirus, accessed on 14 June 2020.

Ragin, C.C., Davey, S., fs/QCA [Computer Program], Version 2.5. University of Arizona, Tucson, 2009, [online] http://www.socsci.uci.edu/ \{\}cragin/fsQCA/software.shtml, accessed on 14 June 2020.

Remuzzi, A., Remuzzi, G., COVID-19 and Italy: What next?, 2020, The Lancet.

Rihoux, B., De Meur, G., Crisp-set qualitative comparative analysis (csQCA). In Configurational Comparative Methods: Qualitative Comparative Analysis (QCA) and Related Techniques; Benoît Rihoux, C.C.R., Ed.; Sage Publications: Shozende Oaks, CA, USA, 2009.

Rihoux, B., Ragin, C., Configurational Comparative Methods: Qualitative Comparative Analysis (QCA) and Related Techniques; Sage Publications: Shozende Oaks, CA, USA, 2012.

Scheffer, M., Critical Transitions in Nature and Society; Princeton University Press: Princeton, NJ, USA, 2009.

Schneider, C.Q., Wagemann, C., Set-Theoretic Methods: A User's Guide for Qualitative Comparative Analysis and Fuzzy Sets in Social Science; Cambridge University Press: Cambridge, UK, 2012.

Short, J.F., The social fabric at risk: Toward the social transformation of risk analysis, 1984, American Sociological Review.

Slovic, P., Perception of risk, 1987, Science.

Slovic, P., The Perception of Risk, Earthscan Publications: London, UK; Sterling, VA, USA, 2000.

Smith, K., Petley, D.N., Environmental Hazards: Assessing Risk and Reducing Disaster, 5th ed.; Routledge: Abingdon, UK, 2009. 
Smith, R.D., Responding to global infectious disease outbreaks: Lessons from SARS on the role of risk perception, communication and management, 2006, Social Science \& Medicine.

Tripp, G., Tan, S., Milne, J., Risk perception and anxiety, 1995, New Zealand Journal of Psychology.

UNDRR, Sendai Framework for Disaster Risk Reduction 2015-2030; UNDRR: Geneva, Switzerland, 2015.

Vineis, P., Public health and the common good, 2014, Journal of Epidemiology and Community Health.

Vineis, P., Public Health as a Common Good. In Health Without Borders; Springer: Cham, Switzerland, 2017.

Wang, J., Wang, Z., Strengths, Weaknesses, Opportunities and Threats (SWOT) Analysis of China's Prevention and Control Strategy for the COVID-19 Epidemic, 2020, International Journal of Environmental Research and Public Health.

WHO, 2015. Scientific Research Advisory Committee on Severe Acute Respiratory Syndrome (SARS). In Proceedings of the First Meeting, Geneva, Switzerland, 20-21 October 2003; WHO: Geneva, Switzerland, 2015.

WHO, 2016, International Health Regulations, 3rd ed.; WHO: Geneva, Switzerland, Volume 2005, 2016.

WHO, 2020. Strengthening the Health System Response to COVID-19; WHO: Geneva, Switzerland, 2020.

Wilder-Smith, A., Chiew, C.J., Lee, V.J., Can we contain the COVID-19 outbreak with the same measures as for SARS?, 2020, The Lancet Infectious Diseases.

Worldometer, 2020. [database] Reported Cases and Deaths by Country, Territory, or Conveyance, [online], https://www.worldometers.info/coronavirus/, accessed on 14 June 2020.

Wu, F., Zhao, S., Yu, B., Chen, Y.-M., Wang, W., Song, Z.-G., Hu, Y., Tao, Z.-W., Tian, J.H., Pei, Y.Y., A new coronavirus associated with human respiratory disease in China, 2020, Nature.

Yan, Y., Shin, W.I., Pang, Y.X., Meng, Y., Lai, J., You, C., Zhao, H., Lester, E., Wu, T., Pang, C.H., The First 75 Days of Novel Coronavirus (SARS-CoV-2) Outbreak: Recent Advances, Prevention, and Treatment, 2020, International Journal of Environmental Research and Public Health.

Zhang, Y., Ma, Z.F., Impact of the COVID-19 Pandemic on Mental Health and Quality of Life among Local Residents in Liaoning Province, China: A Cross-Sectional Study, 2020, International Journal of Environmental Research and Public Health.

Zhou, F., Yu, T., Du, R., Fan, G., Liu, Y., Liu, Z., Xiang, J., Wang, Y., Song, B., Gu, X., Clinical course and risk factors for mortality of adult inpatients with COVID-19 in Wuhan, China: A retrospective cohort study, 2020, The Lancet.

Zhu, N., Zhang, D., Wang, W., Li, X., Yang, B., Song, J., Zhao, X., Huang, B., Shi, W., Lu, R., A novel coronavirus from patients with pneumonia in China, 2019, 2020, The New England Journal of Medicine.

Zimmermann D.H., Reengineering health care: a vision for the future, Eagle Press, Roma, 1994.

\section{Appendix}

\begin{tabular}{|c|c|c|c|c|c|c|}
\hline & $\begin{array}{l}\text { Total } \\
\text { deaths } \\
+\end{array}$ & $\begin{array}{l}\text { Speed of } \\
\text { response } \\
*\end{array}$ & $\begin{array}{l}\text { State of } \\
\text { emergency }\end{array}$ & $\begin{array}{l}\text { International } \\
\text { flights }\end{array}$ & Lockdown & $\begin{array}{l}\text { Borders } \\
\text { and travel }\end{array}$ \\
\hline $\begin{array}{l}\text { Austria } \\
\text { (AT) }\end{array}$ & AMD & Before & No & $\begin{array}{l}\text { Restricted. } \\
\text { Austrian } \\
\text { Airlines } \\
\text { grounted until } \\
\text { April } 19\end{array}$ & $\begin{array}{l}\text { Yes. Internal } \\
\text { movement } \\
\text { banned, except } \\
\text { to go to work, } \\
\text { go shopping, or } \\
\text { visit helath } \\
\text { facilities. } \\
\text { Schools, } \\
\text { universities, } \\
\text { restaurants and } \\
\text { large shops } \\
\text { closed }\end{array}$ & $\begin{array}{l}\text { Open, but } \\
\text { checks and } \\
\text { screenings }\end{array}$ \\
\hline $\begin{array}{l}\text { Belgium } \\
\text { (BE) }\end{array}$ & AMD & After & No & $\begin{array}{l}\text { Brussels } \\
\text { Airlines is } \\
\text { grounded. } \\
\text { Some airlines } \\
\text { flying but } \\
\text { with reduced }\end{array}$ & $\begin{array}{l}\text { Yes, except to } \\
\text { to work, } \\
\text { supermarkets, } \\
\text { health facilities } \\
\text { and to care for } \\
\text { other people. }\end{array}$ & $\begin{array}{l}\text { Closed for } \\
\text { "non } \\
\text { essential" } \\
\text { travel }\end{array}$ \\
\hline
\end{tabular}




\begin{tabular}{|c|c|c|c|c|c|c|}
\hline & & & & service & & \\
\hline $\begin{array}{l}\text { Bulgaria } \\
\text { (BG) }\end{array}$ & BMD & Before & Yes & Stopped & $\begin{array}{l}\text { Yes. } \\
\text { Restrictions on } \\
\text { internal } \\
\text { movement }\end{array}$ & $\begin{array}{l}\text { Restrictions, } \\
\text { travel } \\
\text { screenings } \\
\text { at airports } \\
\text { since March } \\
8\end{array}$ \\
\hline $\begin{array}{l}\text { Croatia } \\
\text { (HR) }\end{array}$ & BMD & Before & No & Stopped & $\begin{array}{l}\text { No national } \\
\text { lockdown, but } \\
\text { restrictions }\end{array}$ & Restrictions \\
\hline $\begin{array}{l}\text { Cyprus } \\
\text { (CY) }\end{array}$ & BMD & Before & No & Stopped & $\begin{array}{l}\text { Yes, internal } \\
\text { movement } \\
\text { banned except } \\
\text { to go work, } \\
\text { grocery } \\
\text { shopping and } \\
\text { medical } \\
\text { treatments or } \\
\text { the bank. } \\
\text { Curfew from } 9 \\
\text { p.m. to } 6 \text { a.m. }\end{array}$ & Closed \\
\hline $\begin{array}{l}\text { Czech Rep. } \\
\text { (CZ) }\end{array}$ & BMD & Before & Yes & Stopped & 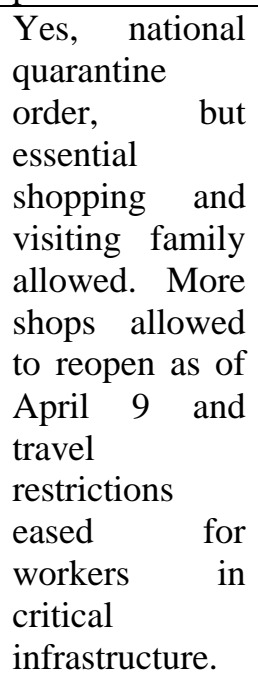 & Closed \\
\hline $\begin{array}{l}\text { Denmark } \\
\text { (DK) }\end{array}$ & AMD & Before & Yes & Stopped & $\begin{array}{l}\text { No national } \\
\text { lockdown, but } \\
\text { schools, } \\
\text { restaurants and } \\
\text { many shops } \\
\text { closed until } \\
\text { May 10. }\end{array}$ & Closed \\
\hline Estonia (EE) & BMD & Before & Yes & Stopped & $\begin{array}{l}\text { No national } \\
\text { lockdown, but } \\
\text { many shops } \\
\text { closed }\end{array}$ & $\begin{array}{l}\text { Restrictions, } \\
\text { helath } \\
\text { screenings } \\
\text { at borders }\end{array}$ \\
\hline Finland (FI) & BMD & Before & Yes & Restricted & $\begin{array}{l}\text { Yes. } \\
\text { Restrictions on } \\
\text { internal } \\
\text { movement }\end{array}$ & $\begin{array}{l}\text { Yes. } \\
\text { Travelling } \\
\text { abroad } \\
\text { banned until } \\
\text { April } 13\end{array}$ \\
\hline France (FR) & AMD & After & Yes & Restricted & $\begin{array}{l}\begin{array}{l}\text { Yes. Provide } \\
\text { form } \\
\text { authorities }\end{array} \\
\end{array}$ & Open \\
\hline
\end{tabular}




\begin{tabular}{|c|c|c|c|c|c|c|}
\hline & & & & & when outside & \\
\hline $\begin{array}{l}\text { Germany } \\
\text { (DE) }\end{array}$ & AMD & After & No & Restricted & $\begin{array}{l}\text { Partial } \\
\text { lockdown, with } \\
\text { rules differing } \\
\text { across states. } \\
\text { Many shops } \\
\text { closed. }\end{array}$ & $\begin{array}{l}\text { Closed for } \\
\text { "non } \\
\text { essential" } \\
\text { travel. } \\
\text { Checks at } \\
\text { borders }\end{array}$ \\
\hline Greece (EL) & BMD & Before & No & $\begin{array}{l}\text { Restricted. } \\
\text { Aegen } \\
\text { Airlines has } \\
\text { suspended all } \\
\text { international } \\
\text { flights, apart } \\
\text { from weekly } \\
\text { flights to } \\
\text { Brussels }\end{array}$ & $\begin{array}{l}\text { Yes. Internal } \\
\text { movement } \\
\text { banned except } \\
\text { to go to work, } \\
\text { grocery } \\
\text { shopping and } \\
\text { for medical } \\
\text { reasons. } \\
\text { Curfew on } \\
\text { island of } \\
\text { Mykonos. }\end{array}$ & $\begin{array}{l}\text { Borders } \\
\text { with } \\
\text { neighboring } \\
\text { Albania, } \\
\text { North } \\
\text { Macedonia } \\
\text { and Turkey } \\
\text { are closed }\end{array}$ \\
\hline $\begin{array}{l}\text { Hungary } \\
\text { (HU) }\end{array}$ & BMD & Before & Yes & Restricted & $\begin{array}{l}\text { No national } \\
\text { lockdown, but } \\
\text { all citizens } \\
\text { asked to stay at } \\
\text { home. } \\
\text { Complusory } \\
\text { home } \\
\text { quarantine } \\
\text { order can be } \\
\text { issued. }\end{array}$ & Closed \\
\hline Ireland (IE) & AMD & After & No & Restricted & $\begin{array}{l}\text { Yes, except for } \\
\text { grocery } \\
\text { shopping and } \\
\text { essential family } \\
\text { visits. Non- } \\
\text { essential shops } \\
\text { closed. }\end{array}$ & No \\
\hline Italy (IT) & AMD & After & Yes & Restricted & $\begin{array}{l}\text { Yes, strict } \\
\text { lockdown nd } \\
\text { non-essential } \\
\text { production } \\
\text { halted. } \\
\text { Bookshops, } \\
\text { stationary } \\
\text { shops and } \\
\text { stores for } \\
\text { children clothes } \\
\text { allowed to } \\
\text { reopen as of } \\
\text { April 14. }\end{array}$ & $\begin{array}{l}\text { Open, but } \\
\text { all } \\
\text { neighboring } \\
\text { countries } \\
\text { have } \\
\text { restricted } \\
\text { entry }\end{array}$ \\
\hline $\begin{array}{l}\text { Luxembourg } \\
\text { (LU) }\end{array}$ & BMD & After & Yes & Stopped & $\begin{array}{l}\text { No national } \\
\text { lockdown, but } \\
\text { non-essential } \\
\text { shops closed } \\
\text { and home } \\
\text { working } \\
\text { advised. }\end{array}$ & No \\
\hline Netherlands & AMD & After & No & Restricted & Yes, & Restrictions \\
\hline
\end{tabular}




\begin{tabular}{|c|c|c|c|c|c|c|}
\hline (NL) & & & & & $\begin{array}{l}\text { exceptions for } \\
\text { shopping. }\end{array}$ & $\begin{array}{l}\text { for Non-EU } \\
\text { citizens }\end{array}$ \\
\hline Poland (PL) & BMD & Before & No & Stopped & $\begin{array}{l}\text { Yes. Non- } \\
\text { essential } \\
\text { movement } \\
\text { banned. }\end{array}$ & Closed \\
\hline $\begin{array}{l}\text { Portugal } \\
\text { (PT) }\end{array}$ & AMD & Before & Yes & Restricted & $\begin{array}{l}\text { Yes. Non- } \\
\text { essential } \\
\text { movement } \\
\text { banned. } \\
\end{array}$ & $\begin{array}{l}\text { Restrictions } \\
\text { at border } \\
\text { with Spain }\end{array}$ \\
\hline $\begin{array}{l}\text { Romania } \\
\text { (RO) }\end{array}$ & BMD & Before & Yes & $\begin{array}{l}\text { Stopped to } \\
\text { Italy, Spain, } \\
\text { Germany and } \\
\text { France }\end{array}$ & $\begin{array}{l}\text { Yes. } \\
\text { Restrictions }\end{array}$ & Restrictions \\
\hline $\begin{array}{l}\text { Slovakia } \\
\text { (SK) }\end{array}$ & BMD & Before & Yes & Stopped & $\begin{array}{l}\text { No, but all } \\
\text { schools closed }\end{array}$ & Closed \\
\hline $\begin{array}{l}\text { Slovenia } \\
\text { (SI) }\end{array}$ & BMD & Before & No & Stopped & $\begin{array}{l}\text { Yes. Non- } \\
\text { essential } \\
\text { movement } \\
\text { banned. } \\
\end{array}$ & Restrictions \\
\hline Spain (ES) & AMD & After & Yes & Yes & $\begin{array}{l}\text { Yes. National } \\
\text { lockdown } \\
\text { extended, non- } \\
\text { essential } \\
\text { economic } \\
\text { activity } \\
\text { stopped. } \\
\text { Certain sectors } \\
\text { allowed to } \\
\text { work again as } \\
\text { of April 14. } \\
\end{array}$ & Restrictions \\
\hline $\begin{array}{l}\text { Sweden } \\
\text { (SE) }\end{array}$ & AMD & After & No & No & No & $\begin{array}{l}\text { Ban on non- } \\
\text { essential } \\
\text { travel since } \\
\text { March } 17\end{array}$ \\
\hline $\begin{array}{l}\text { United } \\
\text { Kingdom } \\
(\mathrm{UK})\end{array}$ & AMD & After & No & No & $\begin{array}{l}\text { Yes, non- } \\
\text { essential } \\
\text { movement } \\
\text { banned, } \\
\text { exceptions for } \\
\text { necessary } \\
\text { shopping, } \\
\text { medical } \\
\text { tratment and } \\
\text { travelling to } \\
\text { work. }\end{array}$ & No \\
\hline
\end{tabular}

Note: + Total deaths as of 15th April 2020: AMD - above-median deaths, BMD - below-median deaths; * Speed of response: Before - first measure was implemented before first death, After - first measure was implemented after first death. Sources: Worldometer; Politico - Coronavirus in Europe and Blavatnik School of Government, University of Oxford: Oxford COVID-19 Government Response Tracker. 